\title{
Effect of gaseous pollutant on vegetable crops and its controlling
}

\author{
Ida Munfarida ${ }^{1 *}$ and Asep Sofyan ${ }^{2}$ \\ ${ }^{1}$ Department of Environmental Engineering, Universitas Islam Negeri Sunan Ampel Surabaya, \\ Surabaya, Indonesia \\ ${ }^{2}$ Department of Environmental Engineering, Institut Teknologi Bandung, Bandung, Indonesia
}

\begin{abstract}
A variety of air pollutants have known harmful effects on human health and the environment, including effects on plants. In Indonesia, these pollutants are the products of combustion from industrial areas and transportation sectors. The effect of air pollution on plant morphology and physiology has been studied. The effects of air pollution on plants are widely seen and damage all plants. This study analysed the effects of gaseous pollutant on vegetable crops, namely, lettuce (Lactuta sativa $\mathrm{L}$ ) and cucumber (Cucumis sativus $\mathrm{L}$ ). The objective of the research was to analyse the effects of exposure of gaseous pollutant on growth of lettuce (Lactuta sativa $\mathrm{L}$ ) and cucumber (Cucumis sativus $\mathrm{L}$ ) in term of both morphology and physiology; thus, from the research we can control vegetable crops from air pollution. Growth parameters include the number of leaves, plant height, fresh weight, dry weight, number of chlorophyll, and stomata index. This research was conducted on Padjadjaran University Greenhouse, Jatinangor. Lettuce and cucumber were given three treatments, plant was contaminated with gaseous pollutant derived from a 2-stroke engine: plants inside and outside the chamber were not contaminated. The results showed that gaseous exposure from 2-stroke engine more affects the growth of lettuce (Lactuca sativa L) than cucumbers (Cucumis sativus L), especially for the following parameters: plant height, dry weight, and fresh weight. Based on the study, air pollutant controlling on vegetable crops includes setting vegetable crops land away from industrial area and transportation sectors, then avoiding open burning after harvesting.
\end{abstract}

\section{Introduction}

A variety of air pollutants have known harmful effects on human health, the environment, including effects on plants. Many researchers have reported that air pollution has become a serious environmental problem for the agricultural sector [1-5]. In Indonesia, these pollutants are the products of combustion from industrial areas and transportation sectors. Increases in both industrialization, urbanization, and associated air pollution threaten urban food production and its quality.

\footnotetext{
*Corresponding author: munfarida@uinsby.ac.id
} 
Effect of air pollution on plant morphology and physiology has been studied. The impact of air pollution on plants are widely seen and damage all plants. The previous study about the effect of air pollution on plant growth has been done by Gostin (2009). Gostin who reported a reduction in the size of stomata and an increase in density of stomata on the leaves of Lotus corniculatus L., Trifolium montanum L., T. pratense L., and T. repens L from the polluted area. In the mesophyll cells (both in palisade and in spongy parenchyma) dark phenolic deposits could be observed [1]. Extensive studies conducted in India have clearly shown significant yield losses in crops due to air pollution [4]. Furthermore, staple crop yields in China have been significantly affected by exposure to air pollution [5]. An empirical model of air pollution showed that future warming and unmitigated ozone pollution could combine to cause an average decline in US wheat, maize, and soybean production by $13 \%, 43 \%$, and $28 \%$, respectively, and a smaller decline for European crops [6].

To provide appropriate air pollution controlling in horticulture crops, we analyzed the effects of the gaseous pollutant on vegetable crops, namely, lettuce (Lactuca sativa L) and cucumber (Cucumis sativus L). The objective of the research was to analyze the effects of exposure of gaseous pollutant on the growth of lettuce (Lactuca sativa $\mathrm{L}$ ) and cucumber (Cucumis sativus L) in term of both morphology and physiology thus from the research we can control vegetable crops from air pollution.

\section{Materials and methods}

\subsection{Area of research}

This research was laboratory scale and was conducted on Padjadjaran University Greenhouse, Jatinangor, Sumedang District, West Java, Indonesia. It is located at 723 meters above sea level. The climate of the area is relatively temperate with an average rainfall of about $2500 \mathrm{~mm}$. The highest temperature recorded was $19-27^{\circ} \mathrm{C}$.

\subsection{Experimental design}

Lactuca sativa L and Cucumis sativus $\mathrm{L}$ were given three treatments, plants were contaminated with gaseous pollutant derived from a 2-stroke engine, and plants inside and outside the chamber were not infected. The chamber was made from wood and covered with plastic.

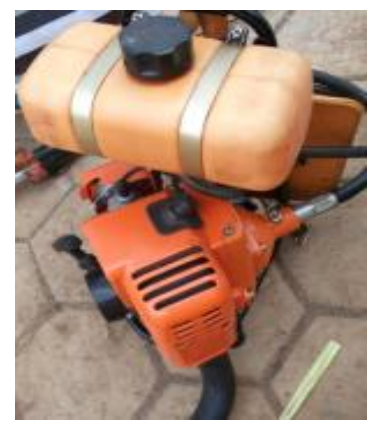

(a)

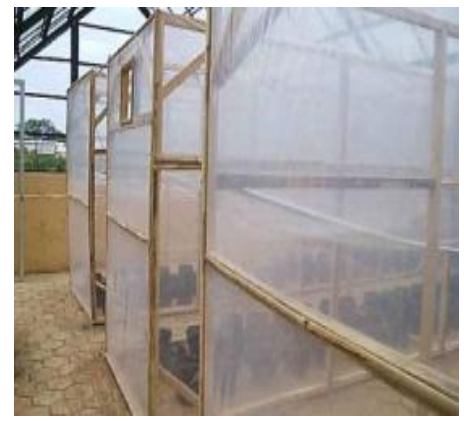

(b)

Fig. 1. Experimental setup (a) 2-stroke engine and (b) chamber design. 


\subsection{Air pollution monitoring}

Pollutant parameters measured in the chamber contaminated with gaseous pollutant derived from a 2-stroke engine were carbon monoxide $(\mathrm{CO})$, hydrocarbons $(\mathrm{HC})$, nitrogen oxide (NO), and nitrogen dioxide $\left(\mathrm{NO}_{2}\right)$. Air pollution was monitored every 15 minutes of 120 minute intervals for 4-four weeks.

\subsection{Plant sampling and analysis}

Plants were grown under field conditions. Plant samples were analyzed every seven days of intervals for 4-four weeks. Growth parameters included the number of leaves, plant height, fresh weight, dry weight, number of chlorophyll, and stomata index.

One-way-analysis of variance (ANOVA) was performed to determine the significant difference between treatments for the different variables and the Least Significant Difference (LSD) test at the $95 \%$ probability level. All the statistical tests were performed using SPSS software (SPSS Inc., version 10.0).

\section{Results}

\subsection{Concentration of gaseous pollutants}

The results of gaseous pollutant concentrations derived from the 2-stroke engine are shown in Fig. 1. During the exposure period, air quality monitoring showed that carbon monoxide (CO) had maximum levels of all five pollutants. The highest maximum level of $\mathrm{CO}$ was $700 \mathrm{mg} / \mathrm{Nm}^{3}$ in the first week.

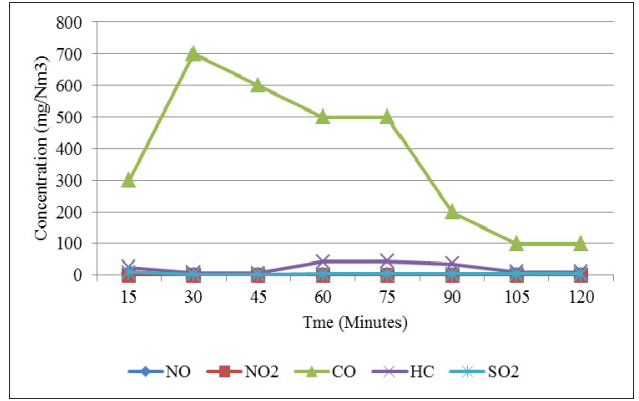

(a)

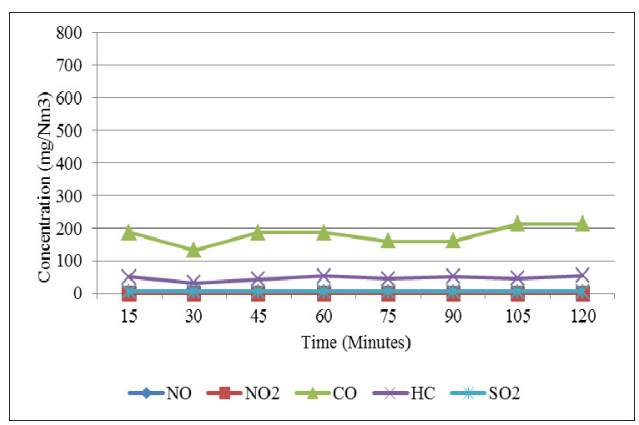

(c)

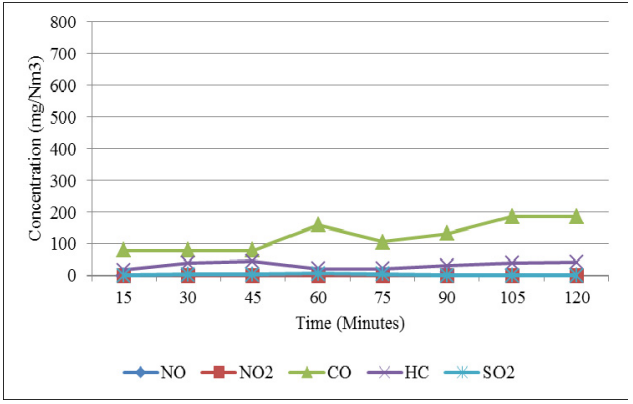

(b)

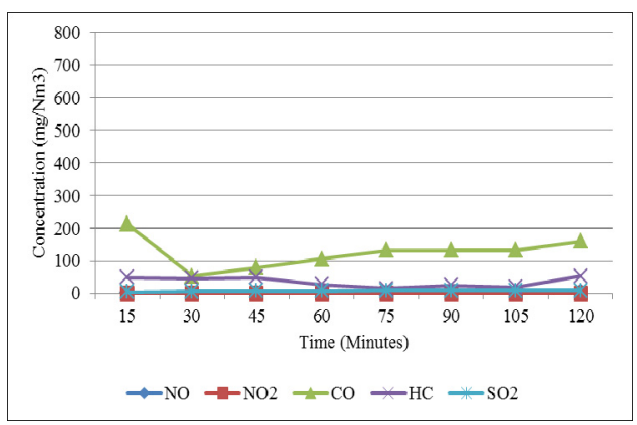

(d)

Fig. 2. Gaseous pollutant concentrations during exposure period. 


\subsection{Plant growth response}

The results of gaseous exposure to the plant growth responses are shown in Table 2, Table 3, and Fig. 3. Plant growth parameters were plant height, number of leaves, plant fresh weight, and plant dry weight.

Table 1. Plant morphology parameters of Lactuca Sativa L exposed to gaseous pollutant.

\begin{tabular}{|c|c|c|c|}
\hline Plant samples & Control outside & Control inside & Gaseous pollutant \\
\hline PH & $35.4167 \mathrm{a}$ & $44.6667 \mathrm{~b}$ & $38.3750 \mathrm{ac}$ \\
\hline NL & $19.1250 \mathrm{a}$ & $21.9583 \mathrm{c}$ & $20.0417 \mathrm{ab}$ \\
\hline PFW & $135.9233 \mathrm{a}$ & $116.1994 \mathrm{~b}$ & $77.0102 \mathrm{c}$ \\
\hline PDW & $12.3829 \mathrm{a}$ & $10.1888 \mathrm{~b}$ & $6.2472 \mathrm{c}$ \\
\hline
\end{tabular}

Table 2. Plant morphology parameters of Cucumis sativus L exposed to gaseous pollutant.

\begin{tabular}{|c|c|c|c|}
\hline Plant samples & Control outside & Control inside & Gaseous pollutant \\
\hline PH & $118.9167 \mathrm{a}$ & $129.6625 \mathrm{~b}$ & $127.0208 \mathrm{~b}$ \\
\hline NL & $13.4583 \mathrm{a}$ & $25.9167 \mathrm{~b}$ & $22.5417 \mathrm{c}$ \\
\hline PFW & $56.6351 \mathrm{a}$ & $69.3773 \mathrm{a}$ & $60.6578 \mathrm{a}$ \\
\hline PDW & $4.5298 \mathrm{a}$ & $6.1328 \mathrm{~b}$ & $4.9551 \mathrm{a}$ \\
\hline
\end{tabular}

Note: $\mathrm{y}=$ Means within columns having different letters are significantly different according to the least significant difference (LSD) at 0.05 level of probability. PH:Plant Height, NL: Number of Leaves, PFW: Plant Fresh Weight, PDW: Plant Dry Weight.

In both plant growth parameters, some differences between the plants from control and polluted chamber were observed. The plant height and the number of leaves of Lactuca sativa $\mathrm{L}$ decreases under the influence of the gaseous pollutants compared to control inside rather than control outside, while the plant fresh and dry weight significantly decreases compared to both controls (Sig $0.000<0.05$ ).

There were no influences of the gaseous pollutants on the reduction on the growth of Cucumis sativus L compared to both controls (Sig $0.000<0.05$ ) for the following parameters, plant height, plant fresh weight, and plant dry weight.

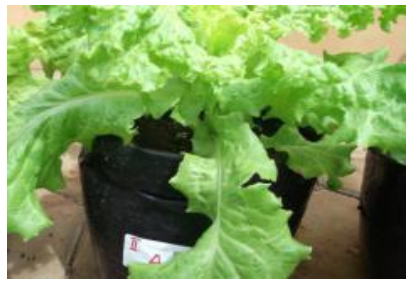

(a)

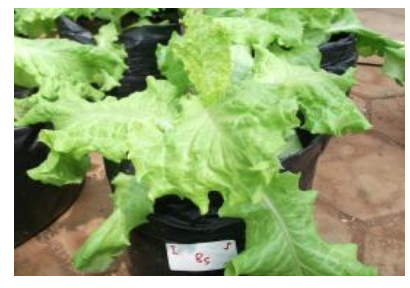

(b)

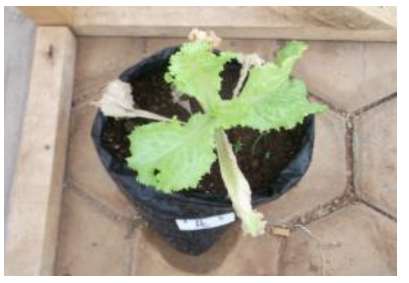

(c)

Fig. 3. Growth Responses of Lactuca sativa L to Gaseous Exposure (a) control outside, (b) control inside, (c) gaseous exposure.

According to the study and statistical test on gaseous pollutant exposure to the plant, it shows that gaseous exposure more affects the morphology of Lactuca sativa L than Cucumis sativus L for the following parameters, plant height, plant fresh weight, and plant 
dry weight. Fig. 3 shows necrosis and chlorosis in the leaves of Lactuca sativa L which is caused by gaseous exposure.

\subsection{Physiological responses}

Physiological parameters were number of chlorophyll and stomata index. The results of physiological response of both plants to gaseous exposure are shown in Fig. 4 and 5.
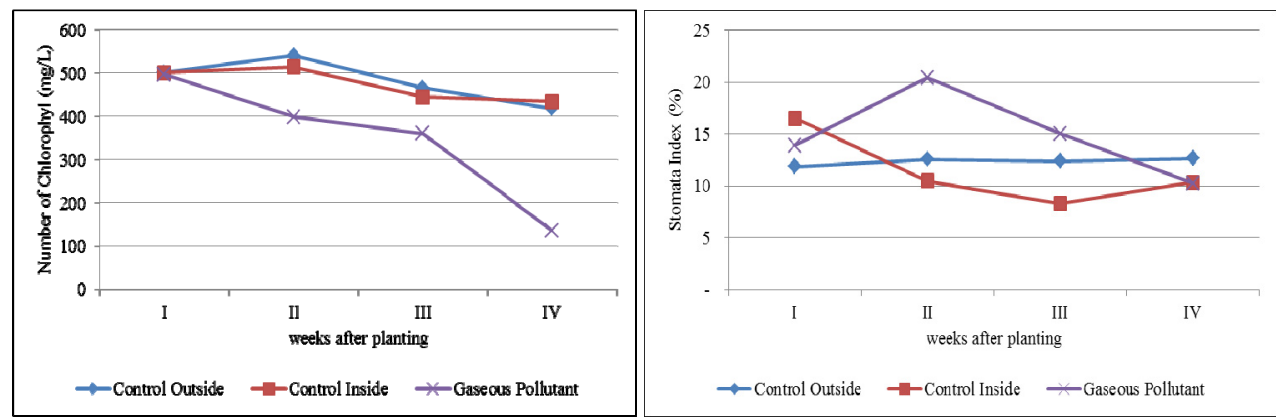

Fig. 4. Physiological responses of Lactuca sativa $\mathrm{L}$ to gaseous exposure.

According to the study, there was reduction on number of chlorophyll and stomata index of Lactuca sativa $\mathrm{L}$ during the gaseous pollutant exposure period compared to control outside and control inside chamber. Reduction in physiological parameter was shown in number of chlorophyll of Lactuca sativa $\mathrm{L}$.
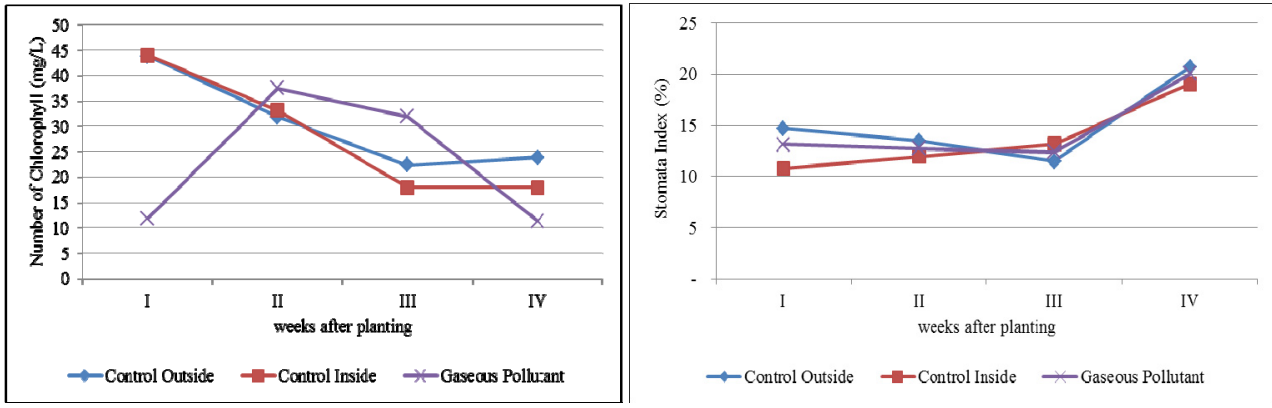

Fig. 5. Physiological Responses of Cucumis sativus L to Gaseous Exposure.

In Cucumis sativus L, no significant differences between the control and the pollutant treatments were noted. According to the study, there was reduction in number of chlorophyll and stomata index of Lactuca sativa L during the gaseous pollutant exposure period rather than Cucumis sativus L compared to control outside and control inside chamber.

\section{Discussion}

According to the study on gaseous pollutant exposure to the plant, it shows that gaseous exposure more affects the morphology of Lactuca sativa $\mathrm{L}$ than Cucumis sativus $\mathrm{L}$ for the following parameters, plant height, plant fresh weight, and plant dry weight.

Previous studies have been done on pollutant for damaging effect to the plant. The primary responses are morphological and on the development of flowers and fruit [7]. Another study concluded that excess substance becomes toxic to the plant. This causes leaf 
chlorosis and root browning. High toxic substance concentration in the nutrient solution along with the appearance of toxicity symptoms significantly depressed the fresh mass of leaves, stems, and roots [8]. Phosphate and nitrogen are plant nutrients in small quantities; excess nutrient will damage the plant. There is a complex change in physiological response due to excess substance. Plant cells may cause lysis and damage. In their study, Naama, Timor, Yinon, Oded, and Yinon (2015) showed that exposure of fungal spores to urban air pollution affects their allergenicity. Upon exposure to air pollution, a complex change in allergenicity occurs. The first modification involves protein nitration that leads to increased allergenicity. The additional detected process of protein deamidation leads to decreased potency with increased exposure, moderating the increase in allergenicity due to nitration $[9]$.

There was an uptake of gas element and compounds by the plant, as a source of nutrient for photosynthesis and respiration: therefore, this may affect plant metabolism. Based on the study, plant in the gaseous chamber affected the growth reduction of the plant. Uptake of gas compounds present in the atmosphere by the plant is well-documented. Deleterious effects from atmospheric $\mathrm{SO}_{2}, \mathrm{NOx}, \mathrm{H}_{2} \mathrm{~S}, \mathrm{NH}_{3}$ are well-documented in the literature [1013]. Ozone causes a wide variety of damage in crops., including visible injury, reduction in photosynthesis, alterations to carbon allocation, and reduction in yield quantity and quality [14-20]. Ozone will cause harm and damage to crop plants by affecting leaf level photosynthesis and senescence (and associated carbon assimilation) as well as full canopy resource acquisition (e.g., water and nutrients) and, ultimately, crop growth and yield [21].

Based on the study, the gaseous exposure more affects the morphology of Lactuca sativa L than Cucumis sativus L. Impact of pollutant depends on the concentrations of elements in the chamber and the physiological status of the plant.

The previous study showed phytotoxicity level of the plant due to environmental contamination as follows: Z. mays $<$ C. sativus $<$ L. Sativa L. The results indicate inhibition in root elongation as the most sensitive toxicity endpoint for L. Sativa L [22]. This study concludes that $C$. sativus $\mathrm{L}$ was a more tolerant vegetable to air pollutant than L. Sativa L. Studies of the responses of tree species to ambient air pollutants for their tolerance or sensitivity have been done by Gao, Catalayud, Garcia-Breijo, Reig Arminana, and Feng (2016), Mukherjee and Agrawal, (2016), Singh, Rao, Agrawal, Pandey, Naryan (1991), and Wen, Kuang, and Zhou (2004) [23-26]. In other studies, the tolerant plant was identified using the GLM approach to assess the responses of tropical trees to urban air pollution concerning leaf functional traits and tree characteristics [27].

According to the study, there was a reduction in a number of chlorophyll and stomata index of Lactuca sativa L during the gaseous pollutant exposure period. Reduction on physiological parameter was shown in an amount of chlorophyll of Lactuca sativa L. A previous study of air pollution effects on leaf structure was done by Gostin (2009), who concluded there were stomata decrease in size and increase in density in leaves from high polluted sites. In the mesophyll cells (both in palisade and in spongy parenchyma) dark phenolic deposits could be observed [1]. Pollution stress may alter the structure of the leaves of Lactuca sativa L; also, the number of chlorophyll and stomata index decreases.

Based on the study, we may conclude that there was an effect of the gaseous pollutant to vegetable crops, especially on the sensitive vegetables. Vegetable planting should consider air pollution to maintain and enhance vegetable productivity. In Indonesia, air pollutants are the products of combustion from industrial areas and transportation sectors which are currently developing. Olivier Janssens-Maenhout, Muntean, and Peters (2016) reported that Indonesia (currently with a share of $1.4 \%$ of the global total $\mathrm{CO}_{2}$ emissions) showed a $4.0 \%$ increase in $\mathrm{CO}_{2}$ emissions in 2015, compared to 2014. These $\mathrm{CO}_{2}$ emissions derived from power and heat generation, other energy industry own use, manufacturing industry, road transport, other transport, residential sector, and other buildings [28]. Therefore, air 
pollutant controlling on vegetable crops includes setting vegetable crops land away from industrial areas and transportation sectors.

In Indonesia, the farmers used to burn crop residue after harvesting: therefore, it may increase air pollutant exposure. Agricultural activities are the primary human source of air pollution in rural areas. Majra (2011) stated that burning of stubble in the field after harvesting, threshing operation, grain dust and large-scale use of tractors, combine harvesters, and diesel operated tube wells are significant factors contributing to air pollution [29]. According to Satyendra Singh and Shaishav (2013), burning of these residues emit gases like sulphur dioxide $\left(\mathrm{SO}_{2}\right)$, nitrogen oxides $(\mathrm{NOx})$, carbon dioxide $\left(\mathrm{CO}_{2}\right)$, carbon monoxide (CO), black carbon (BC), organic carbon (OC), methane $\left(\mathrm{CH}_{4}\right)$, volatile organic compounds (VOC), non-methane hydrocarbons (NMHCs), ozone $\left(\mathrm{O}_{3}\right)$, and aerosols, which affect the global atmospheric chemistry [30]. The burning of crop residues emitted $8.57 \mathrm{Mt}$ of $\mathrm{O}, 141.15 \mathrm{Mt}$ of $\mathrm{CO}_{2}, 0.037 \mathrm{Mt}$ of SOx, $0.23 \mathrm{Mt}$ of $\mathrm{NOx}, 0.12 \mathrm{Mt}$ of $\mathrm{NH}_{3}, 1.46 \mathrm{Mt}$ NMVOC, 0.65 Mt of NMHC, and 1.21 Mt of particulate matter for the year 2008-2009 in India [31]. These air pollutants may distribute in the atmosphere and may affect the crop planting on other areas. Based on fact, the air pollutant controlling on vegetable crops was by avoiding open burning after harvesting. According to Satyendra et .al. (2013), burning of crop residue/ biomass can be avoided by adopting different biochemically/ thermochemically induced techniques. Technologies available for harnessing energy from crop residues are direct combustion, gasification, carbonization, ethanol production, liquefaction, bricking, and pyrolysis [30]. Other researchers suggest using agricultural residues as feedstock for biofuel production [32-33].

\section{Conclusions}

This study highlighted that gaseous exposure for 4-four weeks after planting affects the growth of lettuce (Lactuca sativa L) and cucumbers (Cucumis sativus L). In this study, it showed that gaseous exposure more affects the morphology of lettuce (Lactuca sativa $\mathrm{L}$ ) than cucumber (Cucumis sativus L) for the following parameters: plant height, dry weight, and fresh weight. The gaseous exposure affects the physiology of the lettuce (Lactuca sativa L) more than cucumber (Cucumis sativus L), mainly on the chlorophyll content parameter. We suggest that there was an uptake of gas element and compounds by the plant, as a source of nutrient for photosynthesis and respiration: therefore, this may affect plant metabolism, but excess nutrient will damage the plant. There is a complex change in physiological response due to excess substance. The results suggested that Lactuca sativa $\mathrm{L}$ is more sensitive to gaseous pollutant than Cucumis sativus L. Based on the study, air pollutant controlling on vegetable crops includes setting vegetable crops land away from industrial areas and transportation sectors then avoiding open burning after harvesting. Burning of crop residue/biomass can be avoided by adopting different biochemically/ thermo-chemically induced techniques and using agricultural residues as feedstock for biofuel production.

The author thanks the Ministry of Education, Republic of Indonesia for Collaboration Research with Foreign Researcher and International Publication and Faculty of Environmental Engineering ITB.

\section{References}

1. I.N. Gostin, Not. Bot. Hort. Agrobot. Cluj, 2 (2009)

2. R. Rai, M. Agrawal, S.B. Agrawal, Atmos. Env. 44 (2010) 
3. M. I. Käffer, A. T. Lemos, M. A. Apel, J. V. Rocha, S. M. A. Martins, V. M. F. Vargas, Env. Pollut. 163, 24 (2011)

4. M. Agrawal, B. Singh, M. Rajput, F. Marshall, J.N.B. Bell, Env. Pollut. 126, 323 (2003)

5. W. Miao, X. Huang, Y. Song, J. Env. Sci. 56 (2017)

6. A. P.K. Tai, M. V. Martin, Atmos. Env. 169 (2017)

7. J.N. Cape, Env. Pollut. 122 (2003)

8. S. Doncheva, Z. Stoyanova, Bras. J. Plant Physiol. 14 (2002)

9. L.Y. Naama, S.M. Timor, M. Yinon, Y. Oded, R. Yinon, Sci. Total Env. 541 (2015)

10. L. Davies, J.W. Bates, J. N. B. Bell, P.W. James, O. W. Purvis, Env. Pollut. 146 (2007)

11. L. Paoli, S. Loppi, Env. Pollut. 155 (2008)

12. L. Paolia, S. Arg. Pirintsos, K. Kotzabasis, T. Pisania, E. Navakoudis, Env. Pollut. 158 (2010)

13. S. Loppi, K. Pozo, V.H. Estellano, S. Corsolini, G. Sardella, L. Paoli, Chemosph. 134 (2015)

14. J. Fuhrer, F. Booker, Environ. Int. 29, 141 (2003)

15. J. Fuhrer, Naturwissenschaften 96, 173 (2009)

16. E.L. Fiscus, F. L. Booker, K. O. Burkey, Plant Cell Environ. 28, 997 (2005)

17. M. R. Ashmore, Plant Cell Environ. 28, 949 (2005)

18. R. L. Heath, Environ. Pollut. 155, 453 (2008)

19. E. A. Ainsworth,C. R. Yendrek, S. Sitch, W. J. Collins, L. D. Emberson, Annu. Rev. Plant Biol. 637 (2012)

20. E. A. Ainsworth, Plant J. 90, 886 (2017)

21. L. D. Emberson, H. Pleijel, E. A. Ainsworth, M. van den Berg, W. Ren, S. Osborne, G. Mills, D. Pandey, F. Dentener, P. Büker, F. Ewert, R. Koeble, R.V. Dingenen, Eur. J. Agron. 6, 1161 (2018)

22. K. Masakorala, J. Yao, H. Guo, R. Chandankere, J. Wang, M. Cai, H. Liu, M. M. F. Choi, Water. Air. Soil Pollut. 224, 1553 (2013)

23. F. Gao, V. Calatayud, F. García-Breijo, J. Reig-Armiñana, Z. Feng, Ecol. Indic. 67 (2016)

24. A. Mukherjee, M. Agrawal, Bull. Env. Contam. Toxicol. 96 (2016)

25. S.K. Singh, D.N Rao, M. Agrawal, J. Pandey, D. Naryan, J. Env. Man. 32 (1991)

26. D. Wen, Y. Kuang, G. Zhou, Environ. Sci. Pollut. Res. Int. 11 (2004)

27. A. Mukherjee, M. Agrawal, Ecotoxicol. Env. Saf. 152, 42 (2018)

28. J.G.J. Olivier, G. Janssens-Maenhout, M. Muntean, J. A.H.W. Peters, Trends in Global $\mathrm{CO}_{2}$ emissions: 2016 report (PBL Publishers, European Commission, 2016)

29. J.P. Majra, Air Quality in Rural Areas (INTECH, 2011)

30. T. Satyendra, R.N. Singh, S. Shaishav, Int. Res. J. Earth. Sci. 1, 24 (2013)

31. N. Jain, A. Bhatia, H. Pathak, Aerosol. Air. Qual. Res. 14, 422 (2014)

32. T. Searchinger, R. Heimlich, R. A. Houghton, F. Dong, A. Elobeid, J. Fabiosa, S. Tokgoz, D. Hayes, T. H. Yu, Sci. 319 (2008)

33. N. Sarkar, S. K. Ghosh, S. Bannerjee, K. Aikat. Renew. Energy 37 (2012) 